\title{
SOSIALISASI PENERAPAN ATURAN MENGENAI PENGUASAAN GARASI BAGI PEMILIK KENDARAAN BERMOTOR DI KELURAHAN TURANGGA, KECAMATAN LENGKONG, KOTA BANDUNG
}

\author{
Santi Hapsari, Dewi Adikancana, Abi Ma'ruf Radjab, Adi Nurzaman, Gebby S Veronica, dan Nefi Friyanti \\ Fakultas Hukum, Universitas Padjadjaran \\ Email korespondensi: adi.nurzaman@unpad.ac.id
}

\begin{abstract}
ABSTRAK. Kota Bandung merupakan Ibu Kota Provinsi Jawa Barat yang memiliki kepadatan penduduk yang tinggi serta kondisi daerah yang padat. Kondisi padat penduduk ini berpengaruh pada kelancaran tranportasi di Kota Bandung. Kepadatan penduduk yang tinggi menyebabkan peningkatan jumlah kendaraan, yang tidak diimbangi dengan pertumbuhan jalan dan lahan parkir sehingga menjadi penyebab kemacetan. Kelurahan Turangga merupakan salah satu daerah di Kecamatan Lengkong, Kota Bandung yang sering mengalami kemacetan karena parkir liar yang dilakukan oleh kendaraan yang tidak parkir pada tempat yang semestinya. Melihat kondisi tersebut, Kelurahan Turangga membutuhkan ketentuan pembatasan kendaraan guna mengatasi kemacetan, yang diwujudkan melalui kewajiban memilki/menguasai garasi seperti yang telah diterapkan oleh Provinsi DKI Jakarta berdaarkan Pasal 140 Peraturan Daerah Provinsi DKI Jakarta tentang Transportasi. Berdasarkan hal tersebut, Peneliti bermaksud mempelajari lebih lanjut terkait kemungkinan diberlakukannya ketentuan kepemilikan dan penguasaan garasi di Kelurahan Turangga sebagai solusi kemacetan di daerah tersebut. Metode penelitian yang digunakan adalah pendekatan yuridis normatif dengan spesifikasi penelitian bersifat deskriptif analitis. Teknik pengumpulan data yang dilakukan melalui penelaahan terhadap bahan hukum primer, sekunder, dan tersier, serta melakukan penelitian lapangan kemudian dianalisis secara normatif kualitatif untuk mendapatkan hasil penelitian yang dimaksud.
\end{abstract}

Kata kunci: Garasi; Transportasi; Pembatasan; Kepemilikan; Penguasaan.

ABSTRACT. Bandung is the capital city of West Java which has high population density and congested regional conditions. This densely populated condition influence the fluency of transportation in Bandung. High population density causes an increase in the number of vehicles, which is not matched by the growth of roads and parking areas which are the cause of congestion. Turangga is one of the areas in Lengkong Sub-District, Bandung which often experiences congestion due to illegal parking carried out by vehicles that not parked in proper places. Seeing this condition, Turangga requires provisions on vehicle restriction to overcome congestion, which are realized through the obligation to on a garage as has been implemented by DKI Jakarta based on Article 140 of the Jakarta Regional Regulation No.5 in 2014 concerning Transportation. Based on this, Researched intends to learn more about the possibility of applying garage ownership and possessing a garage in Turangga as a solution to congestion in the area. The research method used is normative juridical approach with descriptive analytical research specification. Data collection techniques were carried out through a review of primary, secondary, and tertiary legal materials, and conducted field research the analyzed qualitatively normative to obtain the research result.

Key words : Garage; Transportation; Restriction; Ownership; Possession.

\section{PENDAHULUAN}

Kota Jakarta sebagai Ibukota negara Repubkik Indonesia merupakan Kota dengan kepadatan penduduk yang tinggi. Kepadatan penduduk yang tinggi ini mempengaruhi munculnya beragam aktivitas yang melibatkan berbagai pihak, aspek dan sistem yang berbeda-beda. Kepadatan penduduk yang tinggi ini khususnya mempengaruhi kondisi tranportasi di Jakarta karena pertumbuhan penduduk yang selalu bertambah tidak diimbangi dengan pertumbuhan fasilitas penunjang tranportasi seperti jalan, angkutan umum dan lain sebagainya. Hal ini menyebabkan berbagai permasalahan di bidang tranportasi, salah satunya kemacetan.

Pemerintah Provinsi DKI Jakarta membentuk Peraturan Daerah Nomor 5 Tahun 2014 tentang Transportasi sebagai solusi atas permasalahan tranportasi darat di DKI Jakarta terutama masalah kemacetan. Perda ini salah satunya mengatur soal kewajiban pemilik kendaraan bermotor mempunyai atau menguasai garasi sebagaimana tercantum dalam Pasal 140 ayat (1) Perda DKI No. 5 Tahun 2014, bahwa setiap orang atau badan usaha pemilik kendaraan bermotor diwajibkan memiliki garasi. Berdasarkan ketentuan tersebut, setiap pemilik kendaraan bermotor wajib memiliki garasi untuk memarkir kendaraannya. Jika tidak memiliki garasi, pemilik kendaraan bermotor harus memiliki jaminan tempat parkir untuk kendaraannya, seperti tempat parkir sewa. Hal ini berkaitan juga dengan ketentuan dalam ayat selanjutnya yaitu Pasal 140 ayat (2) yang menyatakan bahwa kendaraan bermotor dilarang disimpan di ruang milik jalan. Larangan ini diberlakukan mengingat fungsi jalan pada hakekatnya adalah sebagai tempat pelaksanaan lalu lintas yang harus diutamakan dan dibebaskan dari gangguan apapun. Ketentuan mengenai penguasaan garasi ini pada dasarnya diberlakukan guna membatasi jumlah kendaraan dan mengurangi angka parkir liar yang dilakukan oleh kendaraan-kendaraan yang tidak memiliki lahan parkir sehingga parkir di ruang milik jalan dan menghambat lalu lintas di jalan.

Ketentuan mengenai penguasaan garasi sebagai langkah mengatasi kemacetan hendaknya perlu juga diterapkan oleh Kota Bandung mengingat kondisi transportasi di Kota Bandung yang macet karena banyaknya 
parkir liar. Permasalahan parkir liar di Kota Bandung sendiri semakin parah sejak tahun 2014 dan belum dapat terselesaikan hingga sekarang. Maraknya parkir liar ini disebabkan karena kesadaran masyarakat terhadap permasalahan parkir yang masih minim. Hal ini dibuktikan dengan catatan dari Dinas Perhubungan (Dishub) Kota Bandung yang di awal tahun 2018 saja dalam sehari dapat melakukan penindakan terhadap lebih dari 25 (dua puluh lima) kendaraan baik roda dua maupun tempat yang parkir di tempat yang bukan semestinya.

Kelurahan Turangga merupakan salah satu daerah di Kecamatan Lengkong, Kota Bandung yang padat penduduknya. Kepadatan penduduk di Kelurahan Turangga juga mempengaruhi pertumbuhan jumlah kendaraan di daerah tersebut. Pertumbuhan jumlah kendaraan di Kelurahan Turangga yang tidak diimbangi dengan pertumbuhan lahan parkir atau kapasitas garasi pribadi milik penduduk menimbulkan kemacetan karena banyak kendaraankendaraan milik warga yang parkir tidak pada tempatnya yakni di ruas-ruas jalan. Hal ini kemudian menghambat lalu lintas di daerah tersebut apalagi Kelurahan Turangga merupakan daerah yang cukup padat lalu lintasnya karena menjadi jalan penghubung ke daerah lain di Kecamatan Lengkong. Berdasarkan kondisi tersebut, Kelurahan Turangga memerlukan pengetahuan tentang kemungkinan diterapkannya ketentuan penguasaan garasi sebagai jalan keluar atas masalah tranportasi di wilayahnya.

\section{METODE}

r Metode yang digunakan dalam program Pengabdian Pada Masyarakat (PPM) ini yaitu pendidikan masyarakat. Pendidikan masyarakat ini dilaksanakan dalam bentuk sosialiasi kepada masyarakat dan aparatur di Kelurahan Turangga tentang aturan penguasaan garasi dan kemungkinan serta manfaat yang mungkin di dapat oleh Kelurahan Turangga atas penerapan aturan tersebut. Sosialisasi ini ditujukan untuk meningkatkan pemahaman masyarakat dan aparat Kelurahan Turangga tentang pentingnya kesadaran masyarakat terhadap tindakan parkir liar yang dapat menghambat lalu lintas serta merugikan masyarakat di Kelurahan Turangga itu sendiri. Materi yang di sosialisasikan berupa gambaran umum aturan penguasaan garasi di DKI Jakarta serta pelaksanaannya, dan gambaran umum mengenai kondisi kemacetan di Kota Bandung mulai dari penyebab, tingkat kemacetan hingga solusi. Solusi yang ditawarkan dalam sosialisasi tersebut berupa penerapan aturan mengenai penguasaan garasi bagi pemilik kendaraan bermotor. Peserta sosialisasi terdiri dari perwakilan aparatur kelurahan serta perwakilan setiap RT dan RW di Kelurahan Turangga. Adapun sosialisasi disampaikan pada ruang serbaguna Kelurahan Turangga, Kota Bandung.

\section{HASIL DAN PEMBAHASAN}

Pelaksanaan Ketentuan Kepemilikan dan Penguasaan Garasi dalam Pasal 140 Perda DKI Jakarta Nomor 5 Tahun 2014 tentang Transportasi di DKI Jakarta
Kota Jakarta merupakan kota yang memiliki kondisi kepadatan transportasi yang tinggi. Kepadatan trasnportasi di Jakarta sebagian besar disebabkan oleh peningkatan jumlah kendaraan bermotor. Peningkatan jumlah kendaraan bermotor di Jakarta dapat dilihat pada tabel berikut:

\begin{tabular}{|c|c|c|c|c|c|c|}
\hline $\begin{array}{c}\text { Jenis } \\
\text { Kendaraan }\end{array}$ & 2012 & 2013 & 2014 & 2015 & 2016 & $\begin{array}{l}\text { Pertumbuhan } \\
\text { per tahun (\%) }\end{array}$ \\
\hline (1) & (2) & (3) & (4) & (5) & (16) & (7) \\
\hline Sepeda Motor & 10825973 & 11949280 & 13084372 & 13989590 & 13310672 & 5,30 \\
\hline $\begin{array}{l}\text { Mobil } \\
\text { Penumpang }\end{array}$ & 2742414 & 3010403 & 3266009 & 3469168 & 3525925 & 6,48 \\
\hline Mobil Beban & 561918 & 619027 & 673661 & 706014 & 689561 & 5,25 \\
\hline Mobil Bus & 358895 & 360223 & 362066 & 363483 & 338730 & $-1,44$ \\
\hline \multirow[t]{2}{*}{ Ransus } & 129113 & 133936 & 137859 & 139801 & 141516 & 2,32 \\
\hline & 14618313 & 16072869 & 17523967 & 18668056 & 18006404 & 5,35 \\
\hline
\end{tabular}

Berdasarkan tabel diatas, pertumbuhan kendaraan bermotor di Jakarta selama tahun 2012-2016 mencapai 5,35 persen per tahun. Pertumbuhan kendaraan tersebut jika dirinci menurut jenis kendaraan, mobil penumpang mengalami pertumbuhan tertinggi yaitu sebesar 6,48 persen per tahun. ${ }^{1}$

Pertumbuhan kendaraan di DKI Jakarta yang tidak diimbangi dengan pertumbuhan lahan parkir menjadi pemicu kemacetan. Kendaraan-kendaraan banyak di tempatkan di ruang milik jalan sehingga menghambat lalu lintas. Permasalahan ini di tindak lanjuti oleh Pemerintah Provinsi DKI Jakarta dengan membentuk Peraturan Daerah Provinsi DKI Jakarta No. 5 Tahun 2014 tentang Transportasi. Pada Pasal 140 Perda tersebut, terdapat kewajiban memiliki dan/menguasai garasi yang diberlakukan bagi pemilik kendaraan bermotor. Ketentuan ini diwajibkan sebagai syarat tambahan penerbitan STNK.

Ketentuan kepemilikan dan/ penguasaan garasi ini pada perkembangannya sudah diimplementasikan melalui penderekan yang dilakukan oleh Dinas Perhubungan Provinsi DKI Jakarta berdasarkan Surat Keputusan Kepala Dinas Perhubungan Provinsi DKI Jakarta No. 203 Tahun 2017 tentang Standar Operasional Prosedur (SOP) Bidang Pengendalian dan Operasional. Berdasarkan SK tersebut, Dinas Perhubungan Provinsi DKI Jakarta berhak melakukan penderekan terhadap kendaraan-kendaraan yang parkir bukan pada garasi atau pada tempat yang disediakan sebagai garasi, namun di ruang milik jalan dan mengganggu aktivitas masyarakat.

\section{Kebutuhan pengaturan kepemilikan kendaraan bermotor di Kelurahan Turangga, Kota Bandung}

Pada tahun 2016 Kelurahan Turangga tercatat memiliki luas wilayah $166 \mathrm{~m}^{2}$ yang terbagi menjadi 84 RT dan 11 RW dengan total jumlah penduduk mencapai 15.547 jiwa (2899 kepala keluarga). ${ }^{2}$ Kepadatan penduduk di Kelurahan Turanggan mencapai 87,6\%. Kelurahan Turangga menjadi salah satu daerah penghubung di

${ }^{1}$ Badan Pusat Statistik Provinsi DKI Jakarta, Statistik Transportasi DKI Jakarta 2016, Jakarta : BPS Provinsi DKI Jakarta, 2016, hlm. 14.

${ }^{2}$ Kecamatan Lengkong, "Profil dan Tipologi Kecamatan Lengkong Kota Bandung Tahun 2016”, diakses dari ttps://ppid.bandung.go.id/wp-content/ uploads/2017/05/Kecamatan-Lengkong-Dalam-Angka-2016-.pdf 
Kota Bandung yang lalu lintasnya padat. Kepadatan kalu lintas di Kelurahan Turangga ini disebabkan oleh banyaknya kendaraan yang lalu lalang serta banyaknya kendaraan penduduk yang parkir di jalan umum sehingga mengganggu mobilitas kendaraan di daerah tersebut. Berdasarkan hasil wawancara dengan masyarakat setempat, kendaraan-kendaraan yang parkir di jalan karena tidak memiliki garasi ini memang sering dikeluhkan masyarakat karena mengganggu aktivitas masyarakat di daerah tersebut. Gangguan yang dimaksud disini yaitu gangguan mobilitas kendaraan di jalan karena jalanan menjadi sempit serta gangguan yang dialami masyarakat yang di depan rumahnya terparkir kendaraan milik orang lain yang tidak memiliki garasi ataupun kendaraan usaha seperti milik dealer setempat.

Selama ini belum ada ketentuan dan sanksi yang diterapkan bagi kendaraan-kendaraan yang parkir sembarangan di daerah tersebut. Solusi yang diterapkan bagi kondisi-kondisi tersebut selama ini baru sebatas peneguran oleh kantor wilayah (kelurahan) kepada pemilik kendaraan berdasarkan keluhan yang disampaikan oleh masyarakat yang merasa dirugikan. Melalui sosialisasi terkait ketentuan kepemiilikan dan penguasaan garasi bagi pemilik kendaraan bermotor yang sudah diterapkan di Jakarta, masyarakat Kelurahan Turangga menyambut baik kemungkinan diterapkannya ketentuan tersebut. Namun dalam pengadaan ketentuan tersebut harus tetap diperhatikan kepentingan-kepentingan masyarakat yang mungkin juga akan terganggu dengan adanya ketentuan tersebut, misalnya keberadaan tamu yang membawa kendaraan namun pemilik rumah tidak memiliki garasi yang memadai untung menampung kendaraan tamu tersebut. Ketentuan ini nantinya juga harus diberlakukan bukan hanya bagi perorangan namun juga bagi badan usaha seperti dealer atau badan usaha lain yang aktivitasnya seringkali menganggu lalu lintas di daerah tersebut.

\section{SIMPULAN}

Pelaksanaan Program Pegabdian Pada Masyarakat (PPM) melalaui sosialisasi penerapan aturan mengenai penguasaan garasi bagi pemilik kendaraan bermotor di Kelurahan Turangga ini telah mencapai target yang telah ditetapkan yaitu: Warga dan aparatur Kelurahan Turangga sadar akan penyebab kemacetan di Kelurahan Turangga, yaitu kendaraan-kendaraan yang parkir tidak pada tempatnya; Warga dan aparatur Kelurahan Turangga mengetahui ketentuan penguasaan garasi yang telah diterapkan di Jakarta sebagai langkah mengendalikan kemacetan; Warga dan aparatur Kelurahan Turangga menerima usulan terkait kemungkinan diterapkannya ketentuan guna menunjang kelancaran transportasi di Kelurahan Turangga; Warga dan aparatur Kelurahan Turangga memberi masukan terkait hal-hal apa saja yang perlu dipertimbangkan apabila ketentuan penguasaan garasi ini hendak diterapkan di daerah tersebut.

\section{DAFTAR PUSTAKA}

Badan Pusat Statistik Provinsi DKI Jakarta. (2016). Statistik Transportasi DKI Jakarta 2016. Jakarta : BPS Provinsi DKI Jakarta.

Peraturan Daerah Provinsi DKI Jakarta Nomor 5 Tahun 2014 tentang Transportasi.

https://ppid.bandung.go.id/wp-content/uploads/2017/05/ Kecamatan-Lengkong-Dalam-Angka-2016-.pdf 